\title{
The Effect of Nepotism on Organizational Silence, Alienation and Commitment: A Study on Hotel Employees in Turkey
}

\author{
Elbeyi PELİT (Corresponding author) \\ Faculty of Tourism, Afyon Kocatepe University, Afyonkarahisar/Turkey \\ E-mail: elbeyipelit@aku.edu.tr
}

Füsun Istanbullu Dinçer

Department of Tourism Management, İstanbul University, İstanbul/TURKEY

E-mail: istanbul@istanbul.edu.tr

İbrahim Kılıç

Department of Biostatistics, Afyon Kocatepe University, Afyonkarahisar/Turkey

E-mail: kilicibrahim@hotmail.com

Received: April 4, $2015 \quad$ Accepted: May 11, $2015 \quad$ Published: July 1, 2015

doi:10.5296/jmr.v7i4.7806 URL: http://dx.doi.org/10.5296/jmr.v7i4.7806

\begin{abstract}
The aim of this study is to determine the effect of nepotism on organizational silence, alienation and commitment. As a data collecting method a questionnaire which contains nepotism, organizational silence, alienation and commitment scales was used. It was applied on 662 employees working in 30 five star hotels in Turkey. Since nepotism covers the practices in establishments in which family-relative relations are concentrated, the hotels included in the sampling group have been selected from establishments whose proprietors are a part of a family/family group. Factor analysis, Cronbach's Alpha, mean, standard deviation, correlation and regression analysis were used to analyze the acquired data. The study results revealed that nepotism has a positive relationship with organizational silence and alienation and a negative relationship with organizational commitment.
\end{abstract}

Keywords: Nepotism, Organizational silence, Organizational alienation, Organizational commitment, Hotel, Turkey 


\section{Introduction}

The administrative practices carried out to achieve the activities within an organization have a significant impact on the attitudes developed by employees in conjunction with their organizations. In this context it is probable that nepotism which can be defined as "giving no consideration for factors such as skills, capabilities, success and education level etc. or favoring persons without the qualifications required by the job based purely on family or kinship relations" (Masters, 1983; Özler, Özler and Gumüştekin, 2007) will have an impact on silence and alienation which are attitudes that the employees of an organization will develop towards the organization. On the other hand, it can be foreseen that these mentioned practices (nepotism) will have a negative impact on the commitment of employees towards the organization (Brunetto, Shacklock, Bartram, Leggat, Farr-Wharton, Stanton and Casimir, 2012). As a matter of fact, studies on various types of establishments about the topic (Abdalla, Maghrabi and Al-Dabbagh, 1994; 1998; Ciulla, 2005; Hutcheson, 2002; Ichniowski, 1988; Arasl1, Bavik and Ekiz, 2006; Özler et al., 2007; Asunakutlu and Avc1, 2009; 2010; Büte and Tekarslan, 2010; Keleş, Özkan and Bezirci, 2011) emphasize the negative impacts of nepotism in terms of the attitudes/behavior towards work or the organization by employees. Due to the characteristics of the sector/establishments, this situation is particularly valid for service oriented tourism enterprises and may result in negative results for the enterprise in the long term. On the other hand, one of the issues observed during the literature review revealed that the number of studies endeavoring to determine the negative impact of nepotism in terms of the enterprises active in the sector are few. Within this framework, it is important that an empiric study is carried out to determine the existing situation in hotel enterprises which form a significant group within tourism operations and to generate solutions for identified issues. From this point, nepotism was studied in conjuncture with the impact it has on organizational silence, alienation and commitment by developing research hypotheses based on relevant theoretical foundations and a survey was given to 662 employees working in 30 five star hotel operations in three provinces in Turkey which are among the major tourism destinations (Antalya:15, İstanbul:10, Afyonkarahisar:5). The findings were interpreted and recommendations were made to the relevant parties regarding the subject.

\section{Literature Review and Research Hypotheses}

\subsection{Nepotism and Organizational Silence}

In general the concept of nepotism which can be defined as "employing or promoting persons based on family or kinship relations without consideration for factors such as skills, capabilities, success and education level etc." (Masters, 1983; Özler et al., 2007) is derived from the Latin word "nepos" which means "nephew" (Kiechel, 1984; Abdalla et al., 1994; Büte and Tekarslan, 2010), and consists of various acts of favoritism granting privileges at a workplace to relatives or persons based on kinship ties instead of merit (Ford and McLaughlin, 1985; Araslı and Tümer, 2008; Büte, 2011). It can be explained by the social identity theory developed by Tajfel and Turner (1985). According to this theory, people carry out a social comparison by comparing their own groups with other groups as a result of social classification. Generally this social comparison has a tendency to be biased in favor of the 
group which the persons are affiliated with (Hortaçsu, 1998). While individuals are carrying out this comparison, they can obtain a positive social identity and enact upon their instinct to enhance their self respect and perceive their own group superior to the other groups and look down on them. This process of the social identity theory is known as in-group favoritism (Doosje and Ellemers, 1997; Demirtaş, 2003). The theoretical framework drawn and developed regarding nepotism and the functional application actually emerge as a result of the favoritism instinct mentioned in this theory and as the subject is carried into an organizational environment, nepotism becomes one of the major organizational problem groups and generally expresses a negative situation as emphasized in relevant literature (Bayhan, 2002; Abdalla et al., 1994; Abdalla, Maghrabi and Raggad, 1998; Aközer, 2003; Asunakutlu and Avc1, 2010). On the other hand, there are also perspectives which consider that nepotism, particularly in terms of ownership structure, contains elements which contribute to the success of organizations owned by a family or family group. For example a study carried out in Turkey (Özler et al, 2007) states that nepotism created various advantages for employees and that "people felt more secure and comfortable when they encountered a familiar name or figure". Accordingly, some studies (İyiişleroğlu, 2006; Ichinowski, 1988; Abdalla et al, 1998; Hutcheson, 2002; Sadozai, Zaman, Marri and Ramay, 2012) emphasize that appointing family members or favored parties to the administration, particularly in family enterprises, will discourage high level administrators from leaving in the future and even enhance trust and job satisfaction and be an advantage for establishments in this aspect. On the other hand, when the subject is approached from a postmodern social perspective, including their right to strive for the acceptance of their life styles and culture (Saribay, 1994; Bayhan, 2002), this practice (nepotism) will be one of the factors which will downsize the contribution of the employees who are not acquaintances, kith and kin, and relatives and who are a minority. Ultimately this situation is in conflict with contemporary management principles which are based on the paradigm that unlike machines, humans bring their emotions to the organization environment and these emotions are reflected in the way they execute their work (willingness/unwillingness) and based on the essence of nepotism, it can also be considered to be an activity which generates discrimination rather than the acceptance of the mentioned different emotions.

The arguments presented in relevant literature on the disadvantages or advantages of nepotism for organizations do not present a unanimous consensus on the detailed effects particularly in conjunction with the advantages and disadvantages in terms of the sector and type of establishment from an organizational perspective. Also the impact level of nepotism on silence, alienation and commitment are among major topics in organizational behavior which remain unaddressed. It has been observed that no study deals with the situation particularly within the framework of hotel establishments where service operations take place and it is envisioned that studies which aim to determine the existing situation and the impacts for these types of operations where a major part of the work is based on human labor due to the nature of the work would contribute to both the sector and operation literature as well as administrators and employees in terms of the subject. On the other hand, although the concept of "organizational silence" which is accepted as a significant source of problems in organizations is cited as the most significant obstacle preventing desired changes and 
progress from being realized within organizations (Bayram, 2010), there are many dimensions of the subject which still need to be studied (Çakıcı, 2007).

The concept of organizational silence which describes the attitude of employees generated as a consequence of not sharing the feelings, thoughts, ideas, concerns and recommendations they may have regarding their work places, the duties they are tasked with or other activities of the organization entered into the literature of organizational behavior and management with the study carried out by Morrison and Milliken (2000). Morrison and Milliken (2000) defined organizational silence in terms of organizational problems as "a phenomenon on a collective level which is characterized by employees keeping their knowledge, views or concerns about work related issues, problems or challenges to themselves". According to Morrison and Milliken (2000), silence does not only represent opposition but it also arises from lack of information, lack of opportunities to express themselves and from the conviction that it unnecessary to express ideas since it could turn out to be dangerous (Erenler, 2010). According to the "theory of expectation" by Vroom and the "theory of planned behavior" by Ajzen if an individual anticipates that a certain behavior will pave the way to desired results or that it will prevent undesirable results and the individual's prognosis for positive results is high, the individual will be positively inclined to develop a certain behavior. At this point, a positive assessment regarding the expression of ideas openly will enhance the possibility of open speech. However, if the individuals believe that speaking openly will not bring positive results, they may develop attitudes such as speaking is not very important or that nothing will change, and this may result in a more profound silence (Pinder and Harlos, 2001; Dyne, Ang and Botero, 2003; Çakıcı 2007; Erenler, 2010). Also there are two other significant theories on which organizational silence is based, namely "cost benefit analysis" and "the spiral of silence" developed by Noelle-Neumann (1991). Indeed, people discuss the benefits they may obtain in groups and compare the possible cost of speaking by making a cost benefit analysis and behave accordingly. On the other hand, one of the reasons an individual may prefer to remain silent is the risk of the individual voicing of an opinion which does not coincide with the opinions of the group and the fear of being ostracized. Accordingly, people believe that unless they are in the majority, they will not be taken seriously nor their opinions valued or be unwilling to express views and opinions (Premeaux and Bedeian, 2003).

Silence has negative reflections on the organization and employees. The repercussions of silence in organizations are revealed as lack of contributing ideas by employees, ignoring problems, refraining from negative feedback, filtering of information and unresponsiveness in the face of problems. Such behavior obstructs effective decision making, progress and performance enhancement (Morrison and Milliken, 2000; Premeaux, 2001). The negative impact of silence on the employees manifests itself as the individual feeling powerless for speaking frankly about work related problems and concerns, decrease in the feelings of commitment to the organization, sense of belonging, security, appreciation and support, inability to feel job satisfaction and a desire to quit. Remaining silent about subjects that they know and are good at may be painful to employees; the stress brought by the inability to do anything may cause employees to experience psychological stress and feelings of worthlessness (Detert and Edmondson 2005; Barçın, 2012). In addition, silence is a 
significant obstruction for sharing information. The silence of employees may minimize cooperation and by triggering conflict obstruct effective decision making, alternative view points, negative feedback and have a negative impact on decision making and change processes by obstructing correct information (Huang, Vliert Vegt, 2005; Erenler, 2010). Executive and organizational factors (such as mistrusting management, management's apprehension of negative feedback, form of management, fear of ostracism, fear of consequences to other fellow employees, organizational culture, etc.) hold a significant place within this phenomenon, which has negative reflections in general both for individuals as well as organizations (Korsgaard, Roberson and Rymph, 1998; Morrison and Milliken, 2000; Dyne et al., 2003; Çakıc1, 2007; Brinsfield, Edwards and Greenberg, 2009). One of the organizational problems existing particularly in organizationsis the perception that nepotism qualifies as one of the main executive subjects with a significant impact on the silence of employees. The reason is that the phenomenon of silence which contains negative effects in terms of the organization and employees in general will be affected by nepotism and the impacts on organizations will naturally be substantial. In this respect, a study of determining/studying the impact of nepotism which is a significant problem in terms of the healthy functioning of organizations on silence which is another significant source of problem for organizations. Within this scope, the first hypothesis of the study has been developed as follows.

H1: There is a positive correlation between the nepotism perception of hotel employees and the levels of organizational silence (nepotism increases organizational silence).

\subsection{Nepotism and Organizational Alienation}

There is no doubt that nepotism will have a subsiding effect on the morale of employees who are obliged to transact business and work with the relatives of high level executives and feel that a family member is being promoted and awarded without merit (Ichniowski, 1988; Abdalla et al., 1998, Asunakutlu and Avc1, 2010) and harm organizational relations, weaken the bonds between employees, cause a general inefficacy in the work environment (Ichniowski, 1988; Abdalla et al., 1998) and have a negative impact in general on the satisfaction level of employees (Araslı et al., 2006), their sense of security (Keleş et al., 2011) and naturally on the attitudes developed by employees towards their organizations. Alienation, which is another negative attitude developed by employees towards their organizations, can also be assessed in this perspective. The concept of alienation which is generally defined as "a state of a social-psychological disorder consisting of an introverted attitude brought on by a lack of values and by the exclusion from social processes, a status which causes to self-alienate in reality either in his private or organizational life which disrupts his natural functional order, the disengagement of the psycho-social dimensions of human existence and hence disassociation from the essence of self, from his product as well as from his natural and social environment" (Seeman,1967; Tolan, 1981; Pappenheim, 2000) which was first studied systematically by Hegel and later followed by Marx, Durkheim and constituted a subject for several philosophers which were non-empiric studies based on socio-economic, psycho-social and religious grounds. 
The feasibility of empirical studies regarding alienation became debatable in 1959 with Seeman's involvement in the first studies on the dimensions of alienation. Seeman's (1959) study was carried out by addressing alienation in five dimensions which are "powerlessness", "meaninglessness", "anomie" (normlessness), "social isolation" and "self estrangement" in addition to an assessment of the ideas of recognized by social scientists such as Marx, Weber, Durkheim, Merton and Mills (Seeman,1959; Er, 2007). In 1963, a scale, based on the dimensions Seeman's (1959) approach to alienation, was developed by Middleton which included "job alienation" dimension. In the following years, Mottaz (1981) studied the works of Seeman (1959), Middleton (1963) and several other researchers on alienation and addressed the issue in three dimensions namely "powerlessness", "meaninglessness" and "self-estrangement". According to the findings of Mottaz (1981), within each occupational group, perceptions related to personal work values generate different levels of self alienation in the executed work. Therefore, alienation which is the subject of organizational studies is considered as a negative situation which reflects the status of the estranged expectations of individuals on a general level from affiliated organizational structures, values, rules and relations (Şimşek, Çelik, Akgemici and Fettahoğlu, 2006). These antecedent negative aspects pave the way for organizational problems in the organizational environment particularly as loss of job satisfaction and satisfaction in life, low productivity, low motivation, high job stress, low level of loyalty to the work and organization, high level work force turnover and quitting, alienation from work, estrangement from work and low perception of organizational health (Kanungo, 1992; Erkılıç, 2012) which are among the dominating factors which minimize the degree of contribution of the employees to the organization.

Although there are numerous environmental and organizational factors which contribute to the development of alienation by an employee towards the organization, if employees perceive that information flow, employee recruitment and selection, promotion, work division, delegation of authority, relations in the work place and ultimately organizational practices dealing with organizational factors such as execution styles based on nepotism, it is unavoidable that employees will develop an attitude of alienation towards their relevant organizations. Ultimately it has been determined that this situation will causenepotism to have an impact on the alienation of employees against their organizations and it is observed that this subject has not been emphasized in relevant literature. It is remarkable that a significant part of the studies addressing the subject (Padgett and Morris, 2005; Abdalla et al., 1994; 1998; Ciulla, 2005; Ford and McLaughin, 1985; Hutcheson, 2002; Ichniowski, 1988; İyiişleroğlu 2006; Araslı et al., 2006; Özler et al., 2007; Asunakutlu and Avc1, 2010) are studies which endeavor to define the concept, describe the positive and negative aspects as well as reveal the relations with various organizational behavior subjects (job satisfaction, security, cynism, etc.). On the other hand, nepotism is a significant attitude which employees may develop against their organizations and while it is possible to determine that it has an impact on the alienation phenomenon consisting of negative results both for employees as well as organizations, it can be said that there is very little research in the literature addressing this subject. Within this scope the second hypothesis of the study has been developed as follows. 
H2: There is a positive correlation between the nepotism perception of hotel employees and the levels of organizational alienation (nepotism increases organizational alienation).

\subsection{Nepotism and Organizational Commitment}

The commitment of employees towards their organizations is a significant organizational behaviour which is affected by other attitudes towards their organization (job satisfaction, organizational health, burnout, etc.). Organizational commitment which can be defined as "the high level of conviction and acceptance of employees in embracing the goals and values of the organization and resulting strong desire to strive for the goals of the organization, remain within the organization and continue organizational membership" (Mowday, Steers and Porter, 1979) consists of activities which have been generated as a result of the attitude of commitment that individuals have for their organizations (Reichers, 1985) has been studied in relevant literature from various perspectives. The first perspective mentioned above states that commitment is based on an attitudinal or behavioral basis. Accordingly, while scientists studying organizational behavior put emphasis on attitudinal commitment, social psychologists concentrated more on behavioral commitment (Mowday et al, 1979). In advanced stages of the studies, a multifaceted study on the subject of organizational behavior exposed this concept to a three dimensional examination in terms of affective, continuance and normative commitment (Meyer and Allen, 1997). In this context, affective commitment which consists of the first dimension of organizational commitment is defined as the status of employees choosing to remain in the organization as a result of the affection felt by the individuals towards the organization; continuance commitment is dictated by a necessity to remain in the workplace when considering the negative aspects of quitting while in normative commitment employees are prevented from leaving as a result of a feeling bound to the organization by an ethical sense of duty (Meyer, Stanley, Herscovitch and Topolnytsky, 2002). A general assessment of these three approaches reveals that affective commitment which is the first dimension of organizational commitment is based on the desire to remain in the organization; continuance commitment is based on necessity, while normative commitment is based on a sense of obligation (Obeng and Ugboro, 2003; Chen and Francesco, 2003).

One of the most significant issues for the administration of an organization is the level of commitment employees have in executing their duties for the organization and using all their skills and knowledge for their organization. In this context, the characteristics of an employee with a high or low level of organizational commitment are an important path indicator in terms of the success of the organization. For this reason it is very important for every organization that their employees are committed to the organization. On the other hand, hotel operations which hold an important place in the tourism industry are faced with great difficulties in recruiting employees who are committed to the organization. Major efforts are required to enhance the organizational commitment of employees in hotel establishments where staff turnover is high (Birdir 2000; Tarlan and Tütüncü, 2001). Because, with the increase of job satisfaction, performance and self confidence, the organizational commitment of personnel increases and turnover in organizations decreases (Pelit and Kilıç, 2012). The quality of employees employed by hotel establishments and the attitudes they develop against the organization are also important for the organization as well as for ensuring customer 
satisfaction. As a matter of fact, La Lopa (1997) has determined that there is a positive relationship between the organizational commitment of employees and the establishment of good relations with customers.

Considering that the reasoning and attitudes of employees towards the work which has a labor intensive characteristic and towards the hotel establishment itself have a major impact on organizational commitment, one of the important issues will be that these attitudes of the employees will be influenced by acts of nepotism in the organization. Although numerous work related attitude variables which are related to or have an impact on the organizational commitment of employees have been determined in the relevant literature (working conditions, job satisfaction, burnout, empowerment, mobbing etc.), including studies regarding organizational commitment in terms of these determined variables (Vartia 1996; Abdalla et al., 1998; Chebat and Kollias, 2000; Carless, 2004; Padgett and Morriss, 2005; Asunakutlu and Avc1, 2010; Kurkun, Güripek and Aktaş., 2010; Yüksel and Tunçsiper, 2011; Pelit and Kılıç, 2012), studies regarding the relationship status of nepotism and organizational commitment on the attitudes to be developed by employees towards their organizations is yet another area which is limited in the relevant literature. In fact, when variables affecting organizational commitment and their contents are taken into consideration, the perceptions of employees in terms of nepotism may have decisive impact in determining the affective commitment employees will nurture towards their organizations. At this point, nepotism which is perceived as a negative attitude on the whole also harbors characteristics which may have a negative impact on the level of commitment of employees resulting in negativities which are undesirable for the employees (employee recruitment-selection, job design processes, discrimination in promotions, etc.). Thus, by determining the present status of the subject particularly in hotel establishments will contribute both to the sector and establishment administrators and to the relevant literature for taking precautions. Within this scope the third hypothesis of the study has been developed as follows.

H3: There is a negative correlation between the nepotism perception of hotel employees and the levels of organizational commitment (nepotism minimizes organizational commitment).

The research model which has been generated within the theoretical framework and hypotheses presented above for this studyis presented in Figure 1. 


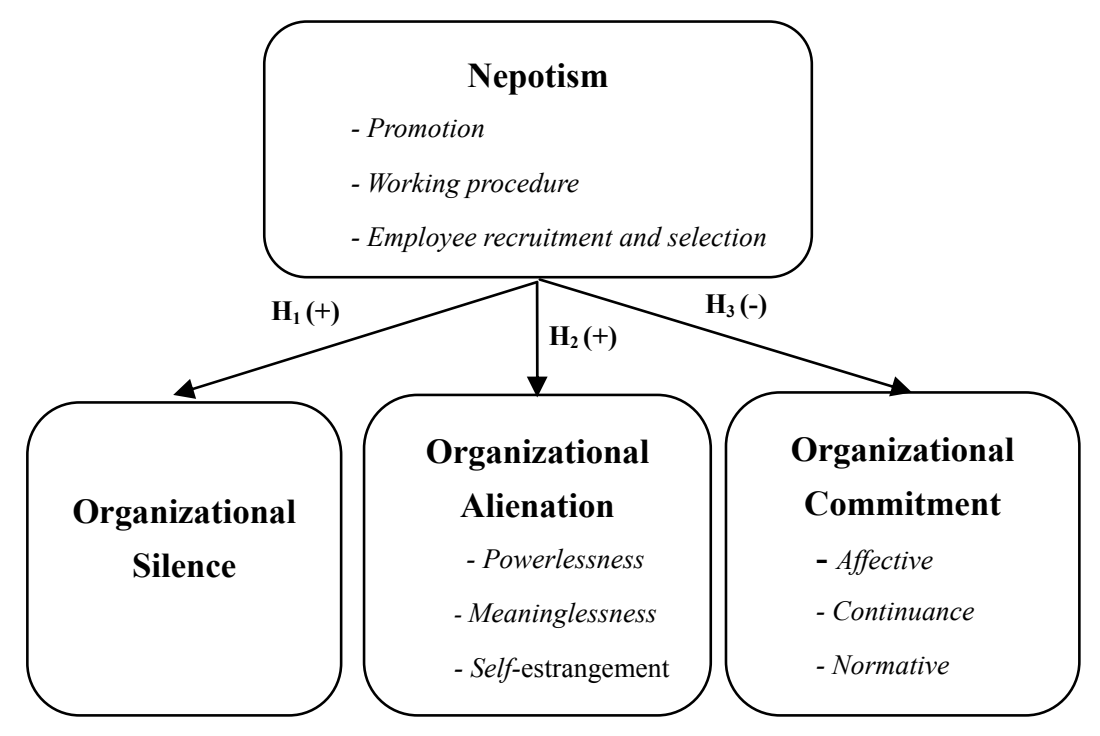

Figure 1. The Research Model

The hypotheses generated regarding the study and the research model presented in Figure 1 requires an answer for the question "Why such a study is necessary?". In this context, in spite of the study results which contained findings ascertaining that nepotism also provided organizations with some advantages, these applications present a situation which is adverse to the professional management structure of modern management mentality particularly. Indeed, a management perception where intrafamilial cooperation and consciousness of interest are deemed superior to ethical values, such as professional sense of duty, responsibility for collective existence and only close contacts are found reliable, also deprive individuals of the skills to establish voluntary civic cooperation (Bayhan, 2002). These applicationsas the determiners of personal and social loyalty, and ultimately loyalty of the social relations within the organization will dispose economic rationality and reveal itself both in employee recruitment and selection as well as favoritism in the execution process of other activities within the organizational environment (Fukuyama, 1998). On the other hand, when considering that nepotism is more widespread in organizations in countries where traditional ties and relationships are valid and the market mechanism has not developed and in particular more evident in the service sector (Özsemerci, 2002, Araslı et al, 2006; Özler et al, 2007), it is inevitable that it is more evident in organizations active in a country such as Turkey which has a high power distance and a society with a collectivist cultural dimension (Hofstede; 1998; Sargut, 2010). Even if this situation could be explained by the internal dynamics of societies/organizations (in Turkey family, close relatives, kith and kin relationships are first and foremost, social solidarity based on traditional criteria, etc.), the situation still contains factors which also restrict creativity on both individual and organizational levels (Bayhan, 2002).

Together with the industrial revolution, employment and employee relations have gained momentum in a scientific direction and particularly with the addition of the "social human" model resulting from the "Hawthorne" study, for nearly a century a "human (employee)" 
centered trend gained acceptance and today the employee is accepted as the main resource of the organization. In this respect, in organizations which are dominated with the contemporary post modern management concept, the employee is assessed as a social entity rather than a "mechanical" model, acting out a role in the execution of work reflecting feelings (Goleman, 2001) which generate attitudes towards both the individuals and the organization and many studies carried out regarding work lives have focused on the reflections of these attitudes on organizations. Particularly because of the negative consequences, silence and alienation are among undesirable employee attitudes from the perspective of organizations, whereas each organization/manager wants their employees to have a high level of organizational commitment because of the positive input it brings. At this point, due to its nature nepotism will increase silence and alienation which are adverse attitudes generated by employees against organizations and have a negative impact on the organizational input. Ultimately, this situation is undesirable both in terms of the organization and the employee and is in conflict with the efforts to achieve a fair management structure which has been a major issue (area of debate) since ancient times (Socrates, Plato) and continues to be a major subject in terms of contemporary modern management and organization theories. As a matter of fact, Arasli et al. (2006), who claimed that nepotism is an unethical behavior, indicated that a study carried out in the relevant subject revealed that nepotism practices in human resources of organizations had a negative impact on the level of justice perceived by the other employees.

As can be observed from the theoretical information given in the previous part of the study, when employees become aware of nepotism in the organization regardless of the activity area, the factors which trigger negative attitudes of employees towards the organizations accompany this awareness. The significance of relevant studies in terms of creating awareness of the situation and taking precautions is an actual topic. On the other hand although relevant literature indicates that nepotism is more common in family and service establishments compared to other types of businesses (Arasl1 et al, 2006; Büte, 2011), it is possible to say that the number of studies which lay down the present situation in hotel establishments is rather limited. Particularly when taking into consideration both the capital and the labor structure of hotel establishments, it is possible to refer to a management structure which may provide an opportunity to exercise nepotism. Indeed, as in the case of Turkey example where the study was carried out, it can be said that in terms of proprietorship (capital) structure where most of the hotels are owned by family groups and the possibility of a structure based on cultural characteristics will provide more opportunities for nepotism which will be a significant basis for tstudying the generated hypotheses. In addition, the research findings gathered in order to determine the existing situation in hotel establishments will contribute to relevant literature as well as awareness and thus contribute to the sector and establishment managers in taking precautions.

\section{Methodology}

\subsection{Sampling and Data Collection}

The target population of the study consisted of five star hotel employees in Turkey. Due to limitations in terms of time and costs, sampling was used in the study. Within this context a 
total of 30 hotels were selected which were sampled with the cluster method (Ural and Kiliç, 2006) out of which 15 were in Antalya representing coastal resort hotels, 10 were in Istanbul representing urban/city hotels, while 5 locations in Afyonkarahisar represented thermal hotels. The reason why the employees of hotel establishments in these regions were selected was because the provinces of Antalya, Istanbul and Afyonkarahisar are the most significant destinations in Turkey in their respective areas of activity and in this context they contain the maximum number of five star hotel establishments. On the other hand, since acts of nepotism are mainly displayed in establishments belonging to family groups, hotels under the proprietorship of a family/family group were included within the scope of the sampling. In this context, since the number of units (employees) consisting of the target population exceeded ten thousand, the sampling volume calculation formula $n=\sigma^{2} \cdot Z_{\alpha}^{2} / d^{2}$ recommended by Özdamar (2001) and Sekaran (2003) for infinite populations ( $\mathrm{n}>10.000)$ and quantitative research was used. A pilot application was carried out on 60 employees for standard deviation $(\sigma)$ and effect size $(d)$ values parameters comprising the formula. Accordingly, the values used for standard deviation was $\sigma=1.2$, effect size was $d=0.1$ and in theory $Z_{\alpha}=1.96$ was appropriated for significant level $\alpha=0.05$ to calculate the minimum sampling volume formula as 554. In addition, 700 face to face surveys were executed in anticipation that the surveys used to collect data may not be filled completely or that they may not be returned and a total of 662 survey forms were assessed. $50.6 \%(n=335)$ of the total 662 employees in the sampling group were employed by five star hotel establishments in Antalya, while $30.4 \%(n=201)$ were employed by such establishments in Istanbul and 19.0 $(n=126)$ were employed in Afyonkarahisar. The distribution of the returned survey forms is directly proportional to the number of five star hotels in Turkey according to type (urban, resort and thermal). $66.6 \%(n=441)$ of the participants were male, $33.4 \%(n=221)$ were female, $32.1 \%$ were university graduates, $53.6 \%$ were high school graduates, $15.3 \%$ were elementary school graduates or less, $71.1 \%$ were married and $28.9 \%$ were single.

The method used in the study to collect data consisted of five parts. Various individual characteristics of the participants were included in the first part, scale factors regarding nepotism were included in the second part while the third part contained organizational silence and the fifth part was dedicated to scale factors regarding organizational commitment. The nepotism scale used for the study consisted of three dimensions (promotion, working procedure, employee recruitment and selection) and 14 items derived from a study carried out by Ford and McLaughin (1985) on the subject and the scale established by Abdalla et al. (1998 "nepotism scale" of Asunakutlu and Avc1 (2010) in which validity and reliability of the scale in Turkey is proved; "employee silence behavior scale" for organizational silence consisting of a single dimension and 12 items established by Erenler (2010) based on his validity and reliability studies of theoretical and applicable works related to organizational silence (Dyne et al, 2003; Amah and Okafor, 2008; Çakıc1, 2008; Tangirala and Ramanujam, 2008; Park and Keil, 2009); the "organizational alienation scale" established by Mottaz (1981) was used for three dimensioned scale (powerlessness, meaninglessness, self-estrangement) consisting 21 items; and for the organizational commitment scale consisting of three dimensions (affective, continuance, normative) and 20 items, the "organizational 
commitment scale-OCQ" developed by Meyer and Allen $(1991,1997)$ were used. The Likert five point scale (1932) type rating was used for the scales in the study. Within this framework the participation levels of the employees in the sampling group is graded as " $1=$ strongly disagree, " $2=$ disagree", " $3=$ neutral", " $4=$ agree", " $5=$ strongly agree".

\subsection{Data Analysis}

The perceptions of nepotism and organizational silence, alienation and commitment levels of the employees in the study were interpreted by calculating the descriptive statistical method employing arithmetical means and standard deviation values. In addition, the Pearson correlation analysis was applied to reveal the relations between the variables. The following characterization was used to interpret the correlation coefficient obtained as a result of the correlation analysis: $0<\mathrm{r}<0.19$ "very poor", $0.20<\mathrm{r}<0.39$ "poor", $0.40<\mathrm{r}<0.59$ "average", $0.60<\mathrm{r}<0.79$ "strong" and $0.80<\mathrm{r}<1.00$ "very strong" (Ural and K1liç, 2006). On the other hand, in order to determine the cause and effect relationship between the variables (the impact of nepotism on silence, alienation and commitment), simple and multiple linear regression models were established. While nepotism was handled as an independent variable in the regression model, organizational silence, alienation and commitment were handled as dependent variables. Factor analysis was used in the study to verify the validity of the scales used in the study and Cronbach's Alpha coefficients were calculated for the validity of reliability. SPSS 17.0 for Windows package program was used in the analysis of the obtained data.

\section{Results and Discussion}

The arithmetical mean and standard deviation values for the factor analysis regarding the scales for nepotism, organizational silence, alienation and commitment in the study (eigenvalues, variance explanation ratio) and reliability analysis (Cronbach's Alpha) results and the nepotism perceptions and levels of organizational silence, alienation, commitment are presented in Table 1.

As a result of the applied factor analysis, the eigenvalue of nepotism is more than 1 and gathered under the three factors which explain the total variance of $76.494 \%$ (promotion, working procedure, employee recruitment and selection). In addition, it has been determined that $71.328 \%$ of the total variance of the silence scale is explained under a single factor, $74.252 \%$ of the total of the alienation scale are explained under three factors (powerlessness, meaninglessness, self-estrangement), while the total variance of $68.094 \%$ of the commitment scale is explained under three factors (affective; continuance; normative). On the other hand, it has been determined that all of the Cronbach's Alpha coefficient values regarding the reliability of the scales exceed the critical value of 0,70 (Harman, 1967; Sekaran, 2003; Morgan, 2004; Ural and Kılıç, 2006) (Table 1). 
Table 1. Some statistics of the scales and subscales

\begin{tabular}{ccccccc}
\hline \multirow{2}{*}{ Factors: Scales and Subscales } & $\begin{array}{c}\text { Number } \\
\text { of Item }\end{array}$ & $\begin{array}{c}\text { Eigen } \\
\text { values }\end{array}$ & $\begin{array}{c}\text { \% of } \\
\text { Variance }\end{array}$ & $\begin{array}{c}\text { Cronbach's } \\
\text { Alpha }\end{array}$ & Means & SD \\
\hline Nepotism: PR & 5 & 10.346 & 32.327 & 0.768 & 2.54 & 1.32 \\
Nepotism: WP & 6 & 9.358 & 29.241 & 0.816 & 2.49 & 1.23 \\
Nepotism: ER & 3 & 4.777 & 14.926 & 0.798 & 2.48 & 1.28 \\
Nepotism (Overall) & $\mathbf{1 4}$ & - & $\mathbf{7 6 . 4 9 4}$ & $\mathbf{0 . 8 7 9}$ & $\mathbf{2 . 5 0}$ & $\mathbf{1 . 2 0}$ \\
\hline Silence (Overall) & $\mathbf{1 2}$ & 9.568 & $\mathbf{7 1 . 3 2 8}$ & $\mathbf{0 . 8 4 1}$ & $\mathbf{2 . 5 6}$ & $\mathbf{1 . 0 0}$ \\
\hline Alienation: powerlessness & 7 & 9.897 & 28.816 & 0.798 & 2.68 & 1.14 \\
Alienation: meaninglessness & 7 & 9.043 & 26.329 & 0.755 & 2.79 & 1.24 \\
$\quad$ Alienation: self-estrangement & 7 & 6.562 & 19.107 & 0.767 & 2.57 & 0.98 \\
Alienation (Overall) & $\mathbf{2 1}$ & - & $\mathbf{7 4 . 2 5 2}$ & $\mathbf{0 . 8 0 9}$ & $\mathbf{2 . 6 8}$ & $\mathbf{1 . 0 0}$ \\
\hline Commitment: affective & 7 & 8.123 & 26.301 & 0.788 & 3.42 & 1.20 \\
Commitment: continuance & 7 & 6.920 & 22.407 & 0.790 & 3.28 & 1.14 \\
Commitment: normative & 6 & 5.987 & 19.386 & 0.762 & 3.25 & 1.17 \\
Commitment (Overall) & $\mathbf{2 0}$ & - & $\mathbf{6 8 . 0 9 4}$ & $\mathbf{0 . 8 3 3}$ & $\mathbf{3 . 3 2}$ & $\mathbf{1 . 1 6}$ \\
\hline
\end{tabular}

Notes: PR: promotion; WP: working procedure; ER: employee recruitment and selection (subdimensions of nepotism)

A study of the averages in Table 1 reveals that nepotism perceptions of the study sampling group $(\overline{\mathrm{X}}=2.50)$ as well as the levels for organizational silence $(\overline{\mathrm{X}}=2.56)$ and alienation $(\bar{X}=2.68)$ are below the mean value of 3 points. These values can be interpreted to mean that the assessment of employees regarding nepotism, silence and alienation is not very negative. However, it has been determined that the levels of organizational commitment of the employees is above average $(\overline{\mathrm{X}}=3.32)$. A study of the average arithmetical values of the subdimensions (sub scales) of nepotism scales reveals that perception points of employees regarding "promotion" ( $\overline{\mathrm{X}}=2.54)$ is higher (more negative) than the perception points for "working procedure" $(\overline{\mathrm{X}}=2.49)$ and "employee recruitment and selection" $(\overline{\mathrm{X}}=2.48)$. This situation shows that employees believe that nepotism is carried out particularly in terms of promotion, an issue which has been emphasized by relevant studies carried out in various sectors in Turkey (Asunakutlu and Avc1, 2010; Büte and Tekarslan, 2010). This result from the study can be explained by associating the "power culture" of Handy (1981) and "individualism-collectivism" organization typologies of Hofstede $(1980 ; 1998)$ in terms of the reflection of culture on organization types. It is particularly common in Turkey that the proprietor of any establishment or family members are on the executive board and family elders are bosses in the organization and considering that those who are not related to or affiliated with the top level management can only get a chance to get somewhere (Erdem, 2007) by showing excessive special effort, it is possible to say that power culture will play a role in the promotion decisions given in an organizational environment (Touron, 2002). Yet, the society in Turkey instead of entering the cultural dimensions of the collectivism of Hofstede $(1980 ; 1998)$ has a structure in which the focus is on the relationship rather than the job and this is reflected in the structures of organizations. In fact, the findings from many 
studies indicate that behavior is also affected particularly on the organizational level of the social culture (Tessema, and Soeters, 2006; Teerikangas and Laamanen, 2002; Erdem, 2007; Sargut, 2010). It is safe to say that promotion applications are likely to be dictated by personal relations (relationship focused) rather than any given standards in the organization structures active in the Turkish community which has a tendency towards the dimension of collectivism culture, while the relations within the organization may be more inclined towards relations with spouse, kith and kin, friends and partiality. On the other hand, this negative situation which is assessed within the scope of nepotism also has a negative reflection on the job satisfaction of employees (Asunakutlu ve Avc1, 2010) as well as their trust in the organization (Keleş et al, 2011) and is problematic in terms of efficiency and performance which is undesirable for the organization and increases the tendency of employees to quit (Araslı et al, 2006).

In addition, although the levels of silence of the employees in the hotel establishment were below average $(\bar{X}=2.56)$, it is still necessary that precautions should be taken in order to further decrease or entirely dispose the levels of employees' silence. Considering that this aspect usually involves the perception of employees regarding top level management, it is necessary that a management concept in which employees feel that the top level is open to listening them, valuing their views and ideas.By this way, employee silence behavior will decrease and employees will be more willing to voice their ideas. Otherwise, the perception of employees that the management level is not open may enhance the tendency to remain silent (Erenler, 2010). Indeed, this aspect has been emphasized in various studies (Saunders, Sheppard, Knight and Roth, 1992; Premeaux and Bedeian, 2003; Amah and Okafor, 2008).

The points for the sub dimensions of the organizational alienation scale for "meaninglessness" being higher $(\overline{\mathrm{X}}=2.79)$ (negative) indicates that the participants are more estranged from the organization in terms of "meaninglessness". On the other hand, it has been determined that the highest levels of organizational commitment in the five star hotel employees in the study is in the affective commitment aspect $(\bar{X}=3.42)$. Another study carried out with hotel employees in Turkey (Erk1lıç, 2012) revealed the same results in which the highest estrangement levels of employees in terms of their organizations have been in the meaninglessness dimension and this situation especially may lead employees to query the goals and significance of the work they are doing and gradually alienate them from their work. On the other hand, the fact that the highest points went to the organizational commitment levels of the employees is a desirable result for the organizations. Particularly, affective commitment, addressed as affectively choosing to remain with an organization by individuals, denotes a display of integration of the employee within the organization and the reason for wishing to remain in the organization is identification with the goals of the organization (Huselid and Day, 1991). Thus, studies carried out on the subject emphasize that employees should primarily have a high level of affective commitment (Brown, 2003).

A correlation matrix for the variables regarding the views of hotel employees on nepotism, organizational silence, alienation and commitment in terms of subdimensions is given in Table 2. 
Table 2. Correlations matrix

\begin{tabular}{|c|c|c|c|c|c|c|c|c|c|}
\hline Variables & 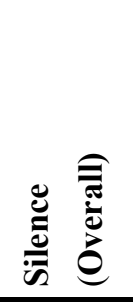 & 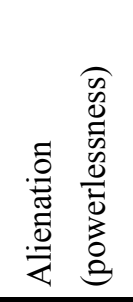 & 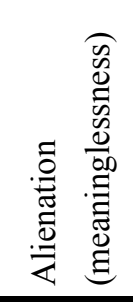 & 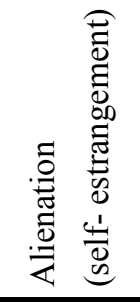 & 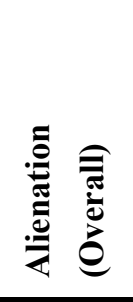 & 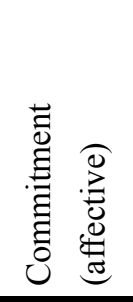 & 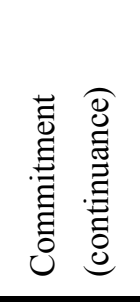 & 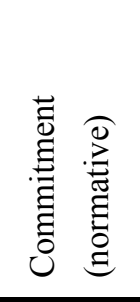 & 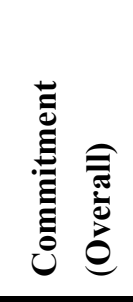 \\
\hline Nepotism (PR) & $0.701^{* *}$ & $0.395^{* *}$ & $0.438^{* *}$ & $0.497^{* *}$ & $0.494^{* *}$ & $-0.357^{* *}$ & $-0.284^{* *}$ & $-0.330^{* *}$ & $-0.402^{* *}$ \\
\hline Nepotism (WP) & $0.747^{* *}$ & $0.375^{* *}$ & $0.536^{* *}$ & $0.545^{* *}$ & $0.542^{* *}$ & $-0.362^{* *}$ & $-0.283^{* *}$ & $-0.308^{* *}$ & $-0.437^{* *}$ \\
\hline Nepotism (ER) & $0.714^{* *}$ & $0.379^{* *}$ & $0.494^{* *}$ & $0.569^{* *}$ & $0.534^{* *}$ & $-0.324^{* *}$ & $-0.282^{* *}$ & $-0.272^{* *}$ & $-0.418^{* *}$ \\
\hline Nepotism (Overall) & $0.766^{* *}$ & $0.408^{* *}$ & $0.520^{* *}$ & $0.570^{* *}$ & $0.556^{* *}$ & $-0.370^{* *}$ & $-0.301^{* *}$ & $-0.322^{* *}$ & $-0.421^{* *}$ \\
\hline Silence (Overall) & 1.000 & $0.503^{* *}$ & $0.549^{* *}$ & $0.644^{* *}$ & $0.628^{* *}$ & $-0.397^{* *}$ & $-0.267^{* *}$ & $-0.334^{* *}$ & $-0.402^{* *}$ \\
\hline Alienation (Overall) & $0,628^{* *}$ & $0,889^{* *}$ & $0,917^{* *}$ & $0,868^{* *}$ & 1,000 & $-0,320^{* *}$ & $-0,208^{* *}$ & $-0,256^{* *}$ & $-0,415^{* *}$ \\
\hline Commitment (Overall) & $-0.402^{* *}$ & $-0.254^{* *}$ & $-0.478^{* *}$ & $-0.370^{* *}$ & $-0.415^{* *}$ & $0.830^{* *}$ & $0.562^{* *}$ & $0.777^{* *}$ & 1.000 \\
\hline
\end{tabular}

Notes: - **: Correlation is significant at the 0.01 level (two-tailed);

PR: promotion; WP: working procedure; ER: employee recruitment and selection (subdimensions of nepotism)

Accordingly, all the correlation coefficients in the table have been found significant $(\mathrm{p}<0.001)$. A study of the correlation coefficients reveals that there is a strong positive correlation between nepotism and subdimensional general organizational silence $(0.60<\mathrm{r}<0.79)$. It has also been determined that there is a positive correlation of medium strength between nepotism and its subdimensions and general organizational alienation $(0.40<\mathrm{r}<0.59)$. In addition a negative correlation of medium strength has been determined between nepotism and its subdimensions and general organizational commitment $(0.40<\mathrm{r}<$ 0.59). The correlation coefficients given in Table 2 show that in terms of the "working procedures" dimension of nepotism, organizational silence $(\mathrm{r}=0.747)$, organizational alienation $(r=0.542)$ and organizational commitment $(r=-0.437)$ have the highest affiliation levels. The analysis results among the variables presented in Table 2 manifest that when the perception of nepotism among employees increases, so does the level of organizational silence and alienation, while the level of organizational commitment decreases (negative impact).

When it is taken into consideration, in terms of both silence and alienation, nepotism is associated on the highest level with assertions/circumstances in conjunction with the execution of procedures, it is inevitable that this will enhance the levels of organizational alienation and silence of the employees and decrease their levels of organizational commitment. Indeed, it is manifested in literature (Asunakutlu and Avc1, 2009; Keleş et al, 2011; Büte; 2011) that this adverse situation which emerges particularly during the execution 
process leaves employees with a lack of organizational trust and has a negative impact on their job satisfaction, motivation, organizational commitment and performance. In addition, the correlation coefficients in Table 2 reveal that there is a strong positive correlation between silence and alienation $(\mathrm{r}=0.628)$, average negative correlation between silence and commitment $(\mathrm{r}=-0.402)$ and an average negative correlation between alienation and commitment $(\mathrm{r}=-0.415)$. Particularly, the high level correlation between silence and alienation which are undesirable features for organizations is a significant indication that they will be accompanied by new organizational problems or increase the existing ones. Especially, remaining silent regarding issues which an employee is experienced and well informed about is upsetting and this may cause the employee to feel disturbed, lose motivation and experience a feeling of helplessness and worthlessness (Morrison and Milliken, 2000; Çakıc1, 2008; Alparslan and Kayalar, 2012). This situation is one of the factors which will increase the attitude of alienation of an employee against his respective organization. On the other hand, relevant studies emphasize that especially alienation (Özbek, 2011; Mercan, 2006) and silence (Çakıcı, 2008, Eroğlu et al, 2011; Barçın, 2012; Alparslan and Kayalar, 2012) have a negative correlation with commitment (decreases commitment) which is verified by the present findings from the hotel employees within the scope of this study. Considering that the reasons pushing employees into silence and alienation against their organizations contain features which will decrease their organizational commitments, the importance of facilitating policies by the managements which will eliminate these reasons becomes obvious.

The results of the simple linear regression analysis carried out in order to reveal the impact of general nepotism on general organizational silence, general alienation and general commitment are given in Table 3.

Table 3. The simple linear regression analyses regarding the correlation between nepotism and organizational silence, alienation and commitment

\begin{tabular}{llcccccc}
\hline $\begin{array}{l}\text { Dependent } \\
\text { variable }\end{array}$ & Model & $\mathrm{b}_{\mathrm{j}}$ & $\mathrm{S}\left(\mathrm{b}_{\mathrm{j}}\right)$ & $\mathrm{t}$ & $\mathrm{p}$ & $\mathrm{R}^{2}$ & ANOVA \\
\hline $\begin{array}{l}\text { Organizational } \\
\text { Silence }\end{array}$ & Constant & 0.969 & 0.058 & 16.767 & $0.000^{* * *}$ & 0.586 & $\mathrm{~F}=934.630$ \\
$\mathrm{n}$ & Nepotism & 0.636 & 0,021 & 30.572 & $0.000^{* * *}$ & & $\mathrm{p}=0.000^{* * *}$ \\
\hline $\begin{array}{l}\text { Organizational } \\
\text { Alienation }\end{array}$ & Constant & 1.528 & 0.075 & 20.421 & $0.000^{* * *}$ & & $\mathrm{~F}=294.809$ \\
\hdashline-0 Nepotism & 0.463 & 0.027 & 17.170 & $0.000^{* * *}$ & 0.309 & $\mathrm{p}=0.000^{* * *}$ \\
\hline $\begin{array}{l}\text { Organizational } \\
\text { Commitment }\end{array}$ & Constant & 4.925 & 0.095 & 51.935 & $0.000^{* * *}$ & & $\mathrm{~F}=141.860$ \\
\hline
\end{tabular}

Notes: Standardized regression coefficients are reported; ***:p<0.001; $b_{j}$ : coefficient; $S\left(b_{j}\right)$ : standard error;

independent variable: nepotism; PR: promotion; WP: working procedure; $\quad$ ER: employee recruitment and selection;

According to the findings in Table 3, a significant linear regression model has been determined between the variables $(\mathrm{p}<0.01)$. The explanation ratio of the model of $\mathrm{R}^{2}=0.586$ calculated between nepotism and organizational silence indicates that $58.6 \%$ of the changes in terms of organizational silence are explained by nepotism. Likewise, $30.9 \%$ of the changes 
in organizational alienation and $17.7 \%$ of the changes in organizational commitment are explained by nepotism. The model obtained through the results of simple regression analysis is presented as follows:

Organizational Silence $=0.969+0.636 \times$ Nepotism

Organizational Alienation $=1.528+0.463 \times$ Nepotism

Organizational Commitment $=4.925-0.407 \times$ Nepotism

The models established in compliance with the regression analysis results reveal that an increase of one unit in nepotism causes an increase of 0.636 units in organizational silence and a 0.463 unit increase in organizational alienation and a decrease of 0.407 units in organizational commitment. The multiple linear regression analysis results obtained from the applications for the subdimensions of nepotism (promotion-PR-, working procedure-WP-, employee recruitment and selection-ER-) on organizational silence, alienation and commitment are given in Table 4.

The findings in Table 4 show that the established regression model is significant $(p<0.01)$. A study of the $t$ values in terms of the significance of the coefficients in the regression models $\left(b_{j}\right)$ reveals that the aspect of nepotism which has the greatest impact on organizational silence, alienation and commitment is the "working process" dimension. This result is supported by the results achieved from the correlation analysis. The multi variable linear models obtained as a result of the analysis are presented as follows.

Organizational Silence $=0.967+0.186 \times \mathrm{PR}+0.296 \mathrm{WP}+0.155 \mathrm{ER}$

Organizational Alienation $=1.529+0.092 \times \mathrm{PR}+0.180 \mathrm{WP}+0.191 \mathrm{ER}$

Organizational Commitment $=4.931-0.069 \times \mathrm{PR}-0.423 \mathrm{WP}-0.081 \mathrm{IA}$ 
Table 4. The multiple linear regression analysis regarding the correlation between nepotism and organizational silence, alienation and commitment

\begin{tabular}{|c|c|c|c|c|c|c|c|}
\hline $\begin{array}{l}\text { Dependent } \\
\text { variable }\end{array}$ & Model & $b_{j}$ & $\mathrm{~S}\left(\mathrm{~b}_{\mathrm{j}}\right)$ & $\mathrm{t}$ & $\mathrm{p}$ & $\mathrm{R}^{2}$ & ANOVA \\
\hline \multirow{4}{*}{$\begin{array}{l}\text { Organizational } \\
\text { Silence }\end{array}$} & Constant & 0.967 & 0.058 & 16.735 & $0.000^{* * * *}$ & \multirow{4}{*}{0.586} & \multirow{4}{*}{$\begin{array}{l}\mathrm{F}=312.816 \\
\mathrm{p}=0.000^{* * *}\end{array}$} \\
\hline & Nepotism (PR) & 0.186 & 0.034 & 5.505 & $0.000^{* * *}$ & & \\
\hline & Nepotism (WP) & 0.296 & 0.051 & 5.795 & $0.000^{* * *}$ & & \\
\hline & Nepotism (ER) & 0.155 & 0.043 & 3.586 & $0.000^{* * *}$ & & \\
\hline \multirow{4}{*}{$\begin{array}{l}\text { Organizational } \\
\text { Alienation }\end{array}$} & Constant & 1.529 & 0.075 & 20.428 & $0.000^{* * *}$ & \multirow{4}{*}{0.311} & \multirow{4}{*}{$\begin{array}{l}\mathrm{F}=99.007 \\
\mathrm{p}=0.000^{* * *}\end{array}$} \\
\hline & Nepotism (PR) & 0.092 & 0.044 & 2.101 & $0.036^{*}$ & & \\
\hline & Nepotism (WP) & 0.180 & 0.056 & 3.214 & $0.002^{* *}$ & & \\
\hline & Nepotism (ER) & 0.191 & 0.066 & 2.895 & $0.004^{* *}$ & & \\
\hline \multirow{4}{*}{$\begin{array}{l}\text { Organizational } \\
\text { Commitment }\end{array}$} & Constant & 4.931 & 0.094 & 52.386 & $0.000^{* * * *}$ & \multirow{4}{*}{0.192} & \multirow{4}{*}{$\begin{array}{l}F=52.594 \\
p=0.000^{* * *}\end{array}$} \\
\hline & Nepotism (PR) & -0.069 & 0.055 & -2.528 & $0.039^{*}$ & & \\
\hline & Nepotism (WP) & -0.423 & 0.083 & -5.093 & $0.000^{* * *}$ & & \\
\hline & Nepotism (ER) & -0.081 & 0.071 & -2.584 & $0.034^{*}$ & & \\
\hline
\end{tabular}

Notes: Standardized regression coefficients are reported; ${ }^{*} p<0.005 ;{ }^{* *} p<0.01 ;{ }^{* * *}: p<0.001$;

PR: promotion; WP: working procedure; ER: employee recruitment and selection

$b_{j}$ : coefficient; $S\left(b_{j}\right)$ : standard error; Independent variable: subdimensions of nepotism

The results of the correlation and regression analyses carried out within the scope of the study contain findings which support the study hypotheses that "nepotism increases the levels of organizational silence and alienation of hotel employees and decreases their level of organizational commitment". Indeed, when considering that nepotism includes favoritism of family members or relatives in an establishment, it is inevitable that the attitudes of silence and alienation in employees against the organizations which are undesirable will increase. When individuals working in the same environment feel that others receive preferential treatment, they will develop negative feelings towards their organization. On the other hand, the possibility that revealing these negative feelings may restrict the other benefits enjoyed by the employee or termination of employment may push him or her into silence when faced with such events and ultimately diminishes motivation and generates helplessness (Abdalla et al, 1998; Asunakutlu and Avc1, 2010) and a feeling of worthlessness pushes the individual into a feeling of alienation towards the organization. This situation will result in a decrease in the feeling of commitment which is a highly esteemed attitude in employees from the perspective of organizations. Especially, if an employee perceives/witnesses that a fellow employee generating the same labor, doing the same job is being favored, it will induce a perception of inability to claim the fruits of his labor which will trigger alienation against the organization.

The proprietors or managers of organizations particularly in societies with excess power distances tend to disassociate their relative groups from the others. In addition, when the tendency to prioritize acting together plays a dominant role, there is a strong possibility that kinship and nepotism will increase (Sargut, 2010). This feature is particularly prevalent in 
Turkish society which has a cultural structure including power distance and collectivism (Hofstede, 1980; 1998) and where the administrators naturally reflect their upbringing into managerial behavior which results in a relationship focused rather than task focused behavioral tendency. When this occurs, organizational efficiency decreases rapidly and organizations are faced with problems in reaching their goals particularly under conditions where human resources lack in quality and where the self control and self management skills of subordinates are insufficient (Wilkinson, Eberhardt, McLaren and Millington, 2005; Sargut, 2010). To this end, this situation which is valid particularly for hotel establishments where the number of employees is more than manufacturing enterprises due to the nature of the work will cause the efficiency of the activities carried out in a hotel establishment to decrease as a whole. Middle and upper level administrators should be particularly aware of this situation and act accordingly and be careful and avoid acts of nepotism which would create a perception of nepotism in the organization.

\section{Conclusion and Implications}

Regardless of the area of activity, the fundamental basis of any organization established for commercial purposes is to earn a profit and in order to earn such a profit it is very important that the activities within the organizational environment should include modern management applications. When the impact of social benefits on the productivity of employees became evident, working conditions have developed in favor of human resources and thus, organizations have been obliged to continuously enhance the working conditions of employees and with the impact exerted by various pressure groups (labor unions, human resources organizations, democratization tendencies, etc.) working conditions have taken a developing trend. However, in addition to this, it is also possible to talk about the presence of significant problems of the subject nowadays. Particularly, the fact that some jobs in the labor-intense establishments active in the tourism sector contain negative conditions in some situations and conditions which are accompanied by major problems and nepotism, organizational silence and alienation hold a key position in these problem groups. Particularly, if an employee feels that due to various reasons (not being a family or relative group member) other colleagues doing the same job is favored by upper management, this situation will become a problem for the employee and this perception will have a negative impact on the job satisfaction, lead the employee to lose trust in the organization as well as motivation (Ichniowski, 1988; Abdalla et al, 1998; Keleş et al, 2011) and thus postpone his or her work which may generate extremely negative results for the organization. Therefore, attitudes of silence and alienation which have negative individual and organizational impacts in general are undesirable traits in employees according to organizations.

Various situations caused by both the structure of the organization, ownership and management structure as well as problematic communication channels may steer employees into these undesirable attitudes regarding their organizations. This situation will ultimately have a negative impact on the feelings of commitment of the employees regarding their organizations. At this point, nepotism is a significant management issue with an impact on both the silence and alienation of employees. There is no doubt that these negative results will have a negative impact on the organizational commitment of employees. A need in terms 
of research into this issue in hotel establishments which employ higher numbers of employees than other types of operations due to the nature of the work has been observed and within this framework a survey regarding the impact of perceptions of nepotism on the levels of organizational silence and alienation as well as organizational commitment was carried out with 662 employees working in five star hotel establishments in three provinces in Turkey which are major tourism destinations (Istanbul, Antalya, Afyonkarahisar).

Although the results of this study revealed that the perception of nepotism of hotel establishment employees in terms of organizational silence and alienation was below average (three points) and showed that these negative attitudes are not common in the organizations, the fact that the employee perceptions for the aspect of "promotion" which is one of the subdimensions of the nepotism scale emerged as higher than the employee perceptions for other aspects shows that a certain amount of nepotism is exercized in hotel establishments in this regard. Although the study also revealed that the organizational commitment levels of employees was above average and the highest type of commitment was found in the level of affective commitment, which is a desirable result for organizations, it is still necessary to concentrate on activities to enhance these attitudes even further.

The correlation and regression analyses carried out in the study revealed the relationship between the perceptions of nepotism of employees with the level of organizational silence and alienation on their commitment levels. For this reason, it is necessary to dispose of these negative aspects in order to enhance the commitment levels. The results of the correlation analysis also revealed that the "working procedure" aspect of nepotism had the highest level of correlation with organizational silence, organizational alienation and organizational commitment. In parallel with the correlation analysis results, the regression analysis results also determined that the aspect having the most significant impact on organizational silence, alienation and commitment was the "working procedure" aspect of nepotism. In addition, the study revealed that the perception of nepotism increased the levels of organizational silence and alienation of five star hotel employees and as a result, the levels of organizational commitment of the employees decreased. The study results in terms of the correlation analysis also determined that with the increase of organizational silence, organizational alienation also increased, while organizational commitment decreased and with the increase of organizational alienation, organizational commitment decreased. Indeed research carried out on the subject (Morrison and Milliken, 2000; Çakıcı, 2008; Alparslan and Kayalar, 2012) emphasize that "silence is disturbing for employees which decreases their motivation and makes them feel worthless and develop attitudes of alienation against their organizations". Similar to the results of this study, relevant literature (Mercan, 2006; Çakıcı, 2008; Eroğlu, Adıgüzel and Öztürk, 2011; Özbek, 2011; Barçın, 2012; Alparslan and Kayalar, 2012) indicates that especially organizational alienation and silence have an inverse (negative) relationship with commitment. Taking the negative impacts of silence and alienation of employees on the feelings of commitment towards the organization into consideration, it is clear that it is necessary for hotel managements to functionalize policies which dispose of these aspects.

The study contains important clues particularly about the structural characteristics of the 
patriarchal Turkish society and the perception that family comes before than the individual and nepotism practices in five star hotel establishments which comprise of the highest level of establishment type and as such are expected to be managed with the highest level of professionalism, as well as the reflections of Turkish bureaucracy and power culture on establishments outside the public sector (private sector). Indeed a study carried out on a country wide scale with university students (Bayhan, 2002) presents important findings in which $90 \%$ of youth in Turkey gave a positive answer to the question "In Turkey the person who has an uncle benefits instead of the one who works hardest" means that the presence of nepotism is not only perceived as organizational, it is also a social perception. The reflection of this situation on organizations is without a doubt also reflected on the findings within the scope of this study and will cause members of organizations, who are not favored, to develop negative attitudes towards their respective organizations (silence, alienation, and decrease in commitment).

It is possible to determine that tourism establishments are places where the differences among employees would be felt more strongly because a major part of tourism establishments active in the service sector (particularly hotel establishments) brings together employees from different cultures, regions and nations and where the work situations and manpower diversity is more than other types of operations (Halıcı, Aktaş, Kasımoğlu and Gruber, 2012). In organizations particularly consisting of individuals with different beliefs, values, attitudes and different cultural codes, the high stress brought on by the excessive competition of the working life in addition to these differences may prepare the ground for employees to develop attitudes in the form of exclusion and alienation against each other (Heames and Harvey, 2006; Tsai, 2010). Instead of integrating the employees, negative aspects such as nepotism, organizational silence and alienation will further deepen these differences and segregate the employees from each other and ultimately cause problems among the organization's employees and if an employee is not kith and kin or a relative and some responsibility has not been fulfilled then such an employee may face aspects of mobbing such as humiliation/contempt (Hoel and Einarsen, 2003; Kaya, 2009). Naturally, this situation will have a negative impact on the sustainability of an operation in the long term. However, no organization proprietor or executive wants the organization to lose money or be wiped off the market in the short term no matter what the activity be or whether executed by a professional executive board or by administrative body members consisting of family members (even majority of the employees), In this context it is inevitable to remove these activities by creating an awareness and a professional management. The greatest responsibility is without a doubt on the executives in management.

The results of the study can be associated and interpreted with the social exchange theory. In this context, the social exchange theory, which particularly endeavors to explain correlative dependent associations, requires that the status of the relationship of one person with another in a relationship on an organizational level is reciprocally dependent and cohesive in terms of exchange (Lambe et al, 2001; Cropanzano and Mitchell, 2005). According to the theory, the parties consider the benefits they will obtain as a result of the exchange with the costs they will bear and develop an attitude or a behavior (Bolat, Bolat and Seymen, 2009). Accordingly, 
if organization management expects employees to increase their contribution to the organization (which is a common goal among organizations) they are obliged to present various opportunities in return and dispose of applications which cause undesirable situations. At this point, according to the social exchange theory which is based on a reciprocal dependency association, organization managements are obliged to put a stop to acts of nepotism which are perceived as negative aspects by employees in order to minimize or eliminate attitudes of silence and alienation which decrease the contribution of employees to organizations and maximize their attitudes of organizational commitment.

This study is particularly significant because it has been carried out in the relevant subject with a certain number of employees employed by various hotel establishments in Turkey and revealed the present status in hotels which are a major type of operation especially in the tourism sector. In addition, the study is important because it involves and compares tourism establishments with other types of establishments as well as those active in different sectors and cultures, establishing awareness of the subject both within relevant sectors and managements, and moreover makes a contribution to the limited literature. Studies carried out in this field through different cultural environments will make it possible to compare organizations culturally and by presenting different practices of the subject in different cultures, the field will significantly gain depth and be enriched. /add depth to the field.

\section{References}

Abdalla, H.F., Maghrabi, A.S., \& Al-Dabbagh, T.H. (1994). Research note: Assessing the effect of nepotism on human resource managers. International Journal of Manpower, 15, 60-67. http://dx.doi.org/10.1108/EUM0000000003933

Abdalla, H.F., Maghrabi, A.S., \& Raggad, B.G. (1998). Assessing the perceptions of human resource managers toward nepotism a cross-cultural study. International Journal of Manpower, 19, 554-570. http://dx.doi.org/10.1108/01437729810242235

Allen, N.J., \& Meyer, J.P. (1990). The measurement and antecedents of affective, continuance and normative commitment to the organization. Journal of Occupational \& Organizational Psychology, 63, 18-38. http://dx.doi.org/10.1111/j.2044-8325.1990.tb00506.x

Alparslan, A.M., and Kayalar, M. (2012). Örgütsel sessizlik: Sessizlik davranişlari ve örgütsel ve bireysel etkileri. Mehmet Akif Üniversitesi Sosyal Bilimler Enstitüsü Dergisi, 4, 136-147.

Aközer, M. (2003). Kamuoyu gözüyle kamuda yolsuzluk. Görüş Dergisi, December, 14-23.

Amah, O.E., \& Okafor, C.A. (2008). Relationships among silence climate, employee silence behaviour and work attitudes: the role of self-esteem and locus of control. Asian Journal of Scientific Research, 1, 1-11. http://dx.doi.org/10.3923/ajsr.2008.1.11

Arasl1, H., Bavik, A., \& Ekiz, E.H. (2006). The effects of nepotism on human resource management, the case of three, four and five star hotels in northern Cyprus. International Journal of Sociologie and Social Policy, 26, 295-308. http://dx.doi.org/10.1108/01443330610680399 
Asunakutlu, T., \& Avcı, U. (2009). Nepotizm-iş tatmini ilişkisi: aile işletmelerinde bir inceleme', 17.Ulusal Yönetim ve Organizasyon Kongresi Bildiriler Kitabl, (pp. 730-736), Balıkesir: Balıkesir Üniversitesi.

Asunakutlu, T., \& Avcı, U. (2010). Aile işletmelerinde nepotizm algisi ve iş tatmini ilişkisi üzerine bir araştirma. Süleyman Demirel Üniversitesi IIIBF Dergisi, 15, 93-109.

Barçın, N. (2012). İşletmelerde örgütsel sessizliğin örgütsel bağlilik ve iş tatminine etkisi üzerine bir araştirma. Master's Thesis, Adanana: Sosyal Bilimler Enstitüsü, Çukurova Üniversitesi.

Bayhan, V. (2002). Demokrasi ve sivil toplum örgütlerinin engelleri: Patronaj ve nepotism. Cumhuriyet Üniversitesi IIIBF Dergisi, 26, 1-13.

Bayram, Y. (2010). Üniversitelerde örgütsel sessizlik., Master's Thesis. Bolu: Abant İzzet Baysal Üniversitesi, Sosyal Bilimler Enstitüsü.

Birdir, K. (2000). Türkiye'de otel genel müdürlerinin iş devir süreleri ve nedenleri üzerine bir araştirma. Anatolia: Turizm Araştırmaları Dergisi, 11, 142-148.

Bolat, O.İ., Bolat, T., \& Seymen, O. (2009). Güçlendirici lider davranişlari ve örgütsel vatandaşlik davranişi arasindaki ilişkinin sosyal mübadele kuramindan hareketle incelenmesi. Balıkesir Üniversitesi Sosyal Bilimler Enstitüsü Dergisi, 2, 215-239.

Brinsfield, C.T., Edwards, M.S., \& Greenberg, J. (2009). Voice and silence in organizations: historical review and current conceptualizations. in Voice and Silence in Organizations, eds. J. Greenberg and M. S. Edwards, (pp. 3-37), England: Emerald Group Publishing.

Brown, B.B. (2003). Employees' organizational commitment and their perception of supervisors' relations-oriented and task-oriented leadership behaviors, Doctoral Dissertation, Virginia: Virginia Polytechnic Institute and State University.

Brunetto, Y., Shacklock, K., Bartram, T., Leggat, S.G., Farr-Wharton, R., Stanton, P., \& Casimir, G. (2012). Comparing the impact of leader-member exchange, psychological empowerment and affective commitment upon australian public and private sector nurses: implications for retention. The International Journal of Human Resource Management, 23, 2238-2255. http://dx.doi.org/10.1080/09585192.2011.616524

Büte, M., \& Tekarslan, E. (2010). Nepotizmin çalişanlar üzerine etkileri: aile işletmelerine yönelik bir saha araştirmasi. Ekonomik ve Sosyal Araştırmalar Dergisi, 6, 1-21.

Büte, M. (2011). Kayırmacılığın çalişanlar üzerine etkileri ile insan kaynaklari uygulamalari ilişkisi: türk kamu bankalarina yönelik bir araştirma. Atatürk Üniversitesi Sosyal Bilimler Enstitüsü Dergisi, 15, 383-404.

Carless, S.A. (2004). Does psychological empowerment mediate the relationship between psychological climate and job satisfaction. Journal of Business and Psychology, 18, 405-425. http://dx.doi.org/10.1023/B:JOBU.0000028444.77080.c5

Chebat, J.C., \& Kollias, P. (2000). The impact of empowerment on customer employees' roles 
in service organizations. Journal of Service Research, 3, 66-81. http://dx.doi.org/10.1177/109467050031005

Chen, Z.X., \& Francesco, A.M. (2003). The relationship between the three components of commitment and employee performance in china. Journal of Vocational Behavior, 62, 490-516. http://dx.doi.org/10.1016/S0001-8791(02)00064-7

Ciulla, J.B. (2005). In praise of nepotism? Business Ethics Quarterly, 15, 153-160. http://dx.doi.org/10.5840/beq20051518

Cropanzano, R. \& Mitchell, M.S. (2005). Social exchange theory: An interdisciplinary review. Journal of Management, 31, 874-900. http://dx.doi.org/10.1177/0149206305279602

Çakıcı, A. (2007). Örgütlerde sessizlik: Sessizliğin teorik temelleri ve dinamikleri. Ç.Ü. Sosyal Bilimler Enstitüsü Dergisi, 16, 145-162.

Demirtaş, H.A. (2003). Sosyal kimlik kurami, temel kavram ve varsayimlar. Iletişim: Araştırmaları Dergisi, 1, 123-14.

Detert, J.R,. \& Edmondson, A.C. (2005). No Exit, No Voice: The Bind of Risky Voice Opportunities in Organizations. Academy of Management Proceedings, 14, 1-6. http://dx.doi.org/10.5465/AMBPP.2005.18780787

Doosje, B., \& Ellemers, N. (1997). Stereotyping under threat: the role of group identification. in The Social Psychology of Stereotyping and Group Life, (pp. 257-273).ed. R. Spears, Oxford: Blackwell.

Dyne, L.V., Ang, S., \& Botero, I.C. (2003). Conceptualizing employee silence and employee voice as multidimensional constructs. Journal of Management Studies, 40, 1359-1392. http://dx.doi.org/10.1111/1467-6486.00384

Er, K. (2007). Çalışanlar açisindan toplam kalite yönetimi yabancilaşma ilişkisi: elektronik sanayi örneği. Uluslararası İnsan Bilimleri Dergisi, 4, 1-40.

Erdem, R. (2007). 'Toplumsal kültürün örgüt kültürüne yansimalari, in Kültürel Bağlamda Yönetsel-Örgütsel Davranış, (pp. 91-133), eds. R. Erdem \& Ç.Ş. Çukur, Ankara: Türk Psikologları Derneği Yayınları.

Erenler, E. (2010). Çalışanlarda sessizlik davranişinin bazi kişisel ve örgütsel özelliklerle ilişkisi: turizm sektöründe bir alan araştirmasi, Doctoral Disertation, Ankara: Hacettepe Üniversitesi, Sosyal Bilimler Enstitüsü.

Erkı1ıç, E. (2012). Örgütsel stresin örgütsel yabancilaşmaya etkisi. Master's Thesis, Afyonkarahisar: Afyon Kocatepe Üniversitesi, Sosyal Bilimler Enstitüsü.

Eroğlu, A.H., Adıgüzel, O., \& Öztürk, U.C. (2011). Sessizlik girdabi ve bağlilik ikilemi: işgören sessizliği ile örgütsel bağlilik ilişkisi ve bir araştirma. Süleyman Demirel Üniversitesi İktisadi ve İdari Bilimler Fakültesi Dergisi, 16, 97-124.

Ford, R., \& McLaughin, F. (1985). Nepotism, Personnel Journal, 64, 57-61. 
Fukuyama, F. (1998). Güven, sosyal erdemler ve refahin yaratilmasi, Ankara: Türkiye İş Bankası Yayınları.

Goleman, D. (2001). Emotional intelligence', in the emotionaly inteligent workplace, (pp.13-26), eds. C.Cherniss and D.Goleman, San Francisco:Jossey-Bass.

Halıc1, A., Aktaş, R., Kasımoğlu, M., \& Gruber, A.G. (2012). Human capital heterogeneity and organzational performance analysis: an empirical study about international hotel chains in Turkey. Emerging Market Journal, 2, 1-7.

Handy, C.B. (1981). Understanding organization (2. Ed.). Aylesbury: Hazell Watson Ltd.

Harman, H. (1967). Modern factor analysis. London: University of Chicago Press.

Heames, J., \& Harvey, M. (2006). Workplace bullying: A cross-level assessment. Management Decision, 44, 1214-1230. http://dx.doi.org/10.1108/00251740610707695

Hofstede, G. (1998). Identifying organizational subcultures: An empirical approach. Journal of Management Studies, 35, 1-12. http://dx.doi.org/10.1111/1467-6486.00081

Hofstede, G., (1980). Culture's consequences. Newbury Park: Sage Publication.

Hoel, H., \& Einarsen, S. (2003). Violence at work in hotels, catering and tourism. Working Paper, Genova: International Labour Office (ILO).

Hortaçsu, N. (1998). Grup içi ve gruplar arasi süreçler. Ankara: İmge Yayınevi.

Huang, X., Vliert, E.V.D., \& Vegt, G.V. (2005). Breaking the silence culture: stimulation of participation and employee opinion withholding cross-nationally. Management and Organization Review, 1, 459-482. http://dx.doi.org/10.1111/j.1740-8784.2005.00023.x

Huselid, N. (1991). Organizational commitment, job involvement, and turnover: a substantive and methodological analysis. Journal of Applied Psychology, 76, 380-391. http://dx.doi.org/10.1037/0021-9010.76.3.380

Hutcheson, O.J. (2002). Negotiating nepotism. Financial Planning, February, 75-76.

Ichniowski, T. (1988). The new nepotism: Why dynasties are making a comeback. Business Week, 31, 106-109.

İyiişleroğlu, S.C. (2006). Aile şirketleri: Adana ve çevresinde faaliyet gösteren aile şirketlerinde nepotizm uygulamasinin tespitine yönelik bir araştirma. Master's Thesis. Adana: Çukurova Üniversitesi, Sosyal Bilimler Enstitüsü.

Kanungo, R.N. (1992). Alienation and empowerment: Some ethical imperatives in business. Journal of Business Ethics, 6, 413-422. http://dx.doi.org/10.1007/BF00870553

Kaya, U. (2009). İşletmelerde yildirma davranişlari (Mobbing): İzmir'de 5 yildizli şehir otellerinde bir araştirma. Master's Thesis. İzmir: Muğla Üniversitesi, Sosyal Bilimler Enstitüsü.

Keleş, H.N., Özkan, T.K., \& Bezirci, M. (2011). A study on the Effects of nepotism, favoritism 
and cronyism on organizational trust in the auditing process in family businesses in Turkey. International Business \& Economics Research Journal, 10, 9-16.

Kiechel, W. (1984). How to relate to nepotism. Fortune, February, 143-144.

Korsgaard, M.A., Roberson, L., \& Rymph, R.D. (1998). What motivates fairness: The role of subordinate assertive behavior on managers interactional fairness. Journal of Applied Psychology, 83, 731-744. http://dx.doi.org/10.1037/0021-9010.83.5.731

Kurkun, A., Güripek, E. \& Aktaş, E. (2010). Nepotizmin çalişanlarin örgütsel adalet algilamalari üzerine etkisi. 18. Ulusal Yönetim ve Organizasyon Kongresi Kitabı, pp. 171-179.

Lalopa, J.M. (1997). Commitment and turnover in resort jobs. Hospitality Research Journal, 21, 11-26. http://dx.doi.org/10.1177/109634809702100202

Likert, R. (1932). A technique for the measurement of attitudes. Archives of Psychology, 22, $1-55$.

Lambe, C. J., Wittmann C.M., \& Spekman, R. (2001). Socail exchange theory and research on business-to-business relational exchange. Journal of Business-to-Business Marketing, 8, 1-36. http://dx.doi.org/10.1300/J033v08n03_01

Masters, R.D. (1983). The biological nature of the state. World Politics, 35, 161-193. http://dx.doi.org/10.2307/2010269

Mercan, M. (2006). Öğretmenlerde örgütsel bağlilik örgütsel yabancilaşma ve örgütsel vatandaşlik. Master's Thesis, Afyon Kocatepe Üniversitesi, Sosyal Bilimler Enstitüsü.

Meyer, J. \& Allen N. (1997). Commitment in the workplace: Theory, research, and application. Thousand Oaks, CA: Sage Publications.

Meyer, J. P., \& Allen, N. J. (1991). 'A Three-component conceptualization of organizational commitment. Human Resource Management Review, 1, 61-89. http://dx.doi.org/10.1016/1053-4822(91)90011-Z

Meyer, J.P., Stanley, D.J., Herscovitch, L., \& Topolnytsky, L. (2002). Affective, continuance, and normative commitment to the organization: A meta-analysis of antecedents, correlates, and consequences. Journal of Vocational Behavior, 2, 20-52. http://dx.doi.org/10.1006/jvbe.2001.1842

Middleton, R. (1963). Alienation, race and education. Americal Sociological Review, 8, 973-977. http://dx.doi.org/10.2307/2090316

Morgan, G. (2004). SPSS for introductory statistics: use and interpretation. USA: Lawrence Erlbaum Associates.

Morrison E.W., \& Milliken F.J. (2000). Organizational silence: A barrier to change and development in a pluralistic world. The Academy of Management Review, 25, 706-725.

Mottaz, C.J. (1981). Some determinants of work alienation. The Sociological Quarterly, 22(4), 515-529. http://dx.doi.org/10.1111/j.1533-8525.1981.tb00678.x 
Mowday, R., Steers, R., \& Porter, L. (1979). The measurement of organizational commitment. $\begin{array}{lllll}\text { Journal of } & \text { Vocational } & \text { Behavior, } & \end{array}$ http://dx.doi.org/10.1016/0001-8791(79)90072-1

Mowday, R.T., Porter, L.W., \& Steers, R.M. (1982). Employee-Organizational linkages: The psychology of commitment, absenteeism and turnover. New York: Academic Press Inc.

Noelle-Neumann, E. (1991). The theory of public opinion: The concept of the spiral of silence. in Communication Yearbook 14, ed. J.A. Anderson, Newbury Park CA: Sage, pp. 256-287.

Obeng, K., \& Ugboro, I. (2003) Organizational commitment among public transit employees: an assessment study. Journal of The Transportation Research Forum, 57, 83-98.

Özdamar, K. (2001). Paket Programlar ve istatistiksel veri analizi (çok değişkenli analizler). Eskişehir: Kaan Yayınları.

Özler, H., Özler, D.E., \& Gümüştekin, G.E. (2007). Aile işletmelerinde nepotizmin gelişim evreleri ve kurumsallaşma. Selçuk Üniversitesi Sosyal Bilimler Enstitüsü Dergisi, 1, 17, 437-450.

Özsemerci, K., Tarhan, R.B., Gençkaya, Ö.F., Ergül, E., \& Özbaran, H. (2002). Türk kamu yönetiminde yolsuzluklar, nedenleri, zararlari ve çözüm önerileri. Master's Thesis, Ankara: TODAİE.

Padgett, M.Y., \& Morris, K.A. (2005). Keeping it all in the familiy": Does nepotism in the hiring process really benetif the beneficiary?'. Journal of Leadership and Organizational Studies, 11, 34-45. http://dx.doi.org/10.1177/107179190501100205

Pappenheim, F. (2000). Alienation in american society. Monthly Review, 52, 36-53. http://dx.doi.org/10.14452/MR-052-02-2000-06_4

Park, C.W., \& Keil, M. (2009). Organizational silence and whistle blowing on it projects: An integrated model. Decision Sciences, 40, 901-918. http://dx.doi.org/10.1111/j.1540-5915.2009.00255.x

Re1chers, A.E. (1985). A review and reconceptualization of organizational commitment. Academy of Management Review, 10, 465-476.

Pelit, E. \& Kılıç, İ. (2012). Mobbing ile örgütsel bağlilik ilişkisi: Şehir ve Sayfiye otellerinde bir uygulama. Işletme Araştırmaları Dergisi, 4, 122-140.

Pinder, C.C. \& Harlos, K.P. (2001). Employee silence: Quiescence and acquiescence as responses to perceived injustice. Research in Personnel and Human Resources Management, 20, 331-369. http://dx.doi.org/10.1016/s0742-7301(01)20007-3

Premeaux, S.F. (2001). Breaking the silence: Toward an understanding of speaking up in the workplace. Doctoral Dissertation, Louisiana State University.

Premeaux, S.F., \& Bedeian, A.G. (2003). Breaking the silence: The moderating effects of self-monitoring in predicting speaking up in the workplace. Journal of Management Studies, 
40, 1537-1562. http://dx.doi.org/10.1111/1467-6486.00390

Sadazai, A.M., Zaman, H.M.F., Marri, M.Y.K., \& Ramay, M.I. (2012). Impact of favorotism, nepotism and cronyism on job satisfaction astudy from public sector of Pakistan, Interdisciplinary Journal of Contemporary Research in Business, 4, 760-771.

Sarıbay, A.Y. (1994). Postmodernite, sivil toplum ve islam. İstanbul: İletişim Yayınları.

Sargut, S. (2010). Kültürlerarası farklilaşma ve yönetim. Ankara: İmge Kitabevi.

Saunders, D.M., Sheppard, B.H., Knight, V., \& Roth, J. (1992). Employee voice to supervisors.

Employee Responsibilities and Rights Journal, 5, 241-259. http://dx.doi.org/10.1007/BF01385051

Seeman, M. (1959). On the meaning of alienation. American Sociological Review, 24, 783-791. http://dx.doi.org/10.2307/2088565

Seeman, M. (1967). Powerlessness and knowledge: A Comparative study of alienation and learning. Sociometry, 30, 105-123. http://dx.doi.org/10.2307/2786221

Sekaran, U. (2003). Research methods for business. New York: John Wiley.

Şimşek, M.Ş., Çelik, A. Akgemici, T., \& Fettahlıoğlu, T. (2006). Örgütlerde yabancilaşmanin yönetimi araştirmasi. Selçuk Üniversitesi Sosyal Bilimler Enstitüsü Dergisi, 15, 569-587

Tajfel, H., \& Turner, J.C. (1985). The social identity theory of intergroup behavior. in psychology of intergroup relations, eds. S. Worchel and W.G. Austin, Chicago: Nelson-Hall, pp. 7-24.

Tangirala, S., \& Ramanujam, R. (2008). Employee silence in critical work issues: The cross level effects of procedural justice climate. Personnel Psychology, 61, 37-68. http://dx.doi.org/10.1111/j.1744-6570.2008.00105.x

Tarlan, D., \& Tütüncü, Ö. (2001). Konaklama işletmelerinde başarim değerlemesi ve iş doyumu analizi. Dokuz Eylül Üniversitesi Sosyal Bilimler Enstitüsü Dergisi, 3(2), 141-163.

Teerikangas, S., \& Laamanen, T. (2002). Dealing with cultural and structural diversityin cross-border R\&D Center Acquisitions. 11th Conference of Global Information Management, 1, pp. 91-108.

Tessema, M.T., \& Soeters, J.L (2006). Challenges and prospects of HRM in developing countries: testing the HRM-performance link in the eritrean Civil Service. The International Journal of Human Resource Management, 17, 86-105. http://dx.doi.org/10.1080/09585190500366532

Tolan, B. (1981). Çăğdaş toplumun bunalimi anomi ve yabancilaşma, (No:166), Ankara: İTİA Yayınları.

Touron, M.M. (2002). Working in Kazakhstan and Russia: Perception of French managers. The International Journal of Human Resource Management, 13, 213-231. http://dx.doi.org/10.1080/09585190110102341 


\section{Macrothink}

Journal of Management Research

ISSN 1941-899X 2015, Vol. 7, No. 4

Tsai, C.J. (2010). HRM in SMEs: Homogeneity or heterogeneity? A study of Taiwanese high-tech firms. The International Journal of Human Resource Management, 21, 1689-1711.

http://dx.doi.org/10.1080/09585192.2010.500490

Ural, A., \& Kılıç, İ. (2006). Bilimsel araştirma süreci ve spss ile veri analizi (SPSS 10.00 - 12.0 For Windows), Ankara: Detay Yayınc1lık.

Vartia, M. (1996). The sources of bullying-psychological work environment and organizational climate. European Journal of Work and Organizational Psychology, 5, 203-214. http://dx.doi.org/10.1080/13594329608414855

Wilkinson, B., Eberhardt, M., McLaren, J., \& Millington, A. (2005). Human resource barriers to partnership sourcing in China. The International Journal of Human Resource Management, 16(10), 1886-1900. http://dx.doi.org/10.1080/09585190500298578

Yüksel, M., \& Tunçsiper, B. (2011). The relationship between mobbing and organizational commitment in workplace. International Review of Management and Marketing, 1, 54-64.

Zheng, X.T., Ke, J.L., Shi, J.T., \& Zheng, X.S. (2008). Survey on employee silence and the impact of trust on it in China. Acta Psychologica Sinica, 40, 219-227. http://dx.doi.org/10.3724/SP.J.1041.2008.00219 